\title{
Toward an analytical framework for understanding complex social- ecological systems when conducting environmental impact assessments in South Africa
}

\author{
$\underline{\text { Rebecca Bowd }}^{1}, \underline{\text { Nevil W. Quinn }}^{2}$ and Donovan C. Kotze ${ }^{1}$
}

ABSTRACT. Consideration of biophysical impacts has historically dominated environmental impact assessment (EIA) practice. Despite the emergence of social impact assessment, the consideration of socioeconomic impacts in EIA is variable, as is the extent of their integration in EIA findings. There is growing recognition for the need to move EIA practice toward sustainability assessment, characterized by comprehensiveness, i.e., scope of impacts, integration, i.e., of biophysical and socioeconomic impacts, and a greater strategic focus. This is particularly the case in developing regions and in countries like South Africa, which have statutory requirements for the full consideration of socioeconomic impacts in EIA. We suggest that EIA practice could benefit from incorporating evolving theory around social-ecological systems (SES) as an effective way of moving toward sustainability assessment. As far as we are aware, our study constitutes the first attempt to apply and formalize SES constructs to EIA practice within a regulated procedure. Our framework goes beyond conventional scoping approaches reliant on checklists and matrices by requiring the EIA practitioner to cocreate a conceptual model of the current and future social-ecological system with the implicated communities. This means social and biophysical impacts are assessed integratively, and that communities participate meaningfully in the EIA process, thereby helping address two of the most common shortfalls of EIA practice. The framework was applied in two case studies, establishment of communitybased accommodation linked to existing tourism infrastructure (Eastern Cape, South Africa), and a proposed wine estate (KwaZuluNatal, South Africa). The framework revealed impacts, which would not be considered in a biophysically-oriented EIA, and helped identify development synergies and institutional and governance needs that are equally likely to have been overlooked. We suggest the framework has value as a counterpoint to established approaches and could contribute to improving the quality of EIAs with respect to the complex SESs that characterize the developing world.

Key Words: ecosystem services; environmental impact assessment (EIA); framework; participation; social-ecological system (SES); sustainability assessment

\section{INTRODUCTION}

Environmental Impact Assessment (EIA) is globally recognized as a principal tool in environmental management, entrenched in domestic and international law (Ortolano and Shepherd 1995, Morgan 2012). Fundamental to EIA practice is consideration of the interrelationships between the social, economic, and biophysical aspects of a project (IAIA 1999), and early principles for the design and development of effective EIA processes. Fuller (1999:57) acknowledged that their scope should extend to "all aspects of a proposal, including cumulative effects, interrelated socioeconomic, cultural and health factors and sustainability implications." In practice however, EIAs have dealt predominantly with biophysical impacts, leading social impact assessment (SIA) to be described as the "poor relation" and "orphan" of the EIA process in the United States and the United Kingdom (Glasson and Heaney 1993, Burdge 2002, Chadwick 2002). The resulting debate stimulated development of international principles for social impact assessment (Vanclay 2003:6) acknowledging that good practice in SIA "accepts that social, economic and biophysical impacts are inherently and inextricably interconnected." Although SIA has since emerged as a specialized area within EIA, compared to "biophysical issues, SIA usually has a minor role" (Esteves et al. 2012), and consideration of socioeconomic impacts in EIA globally is variable and often very weak (Glasson et al. 2012). When they are assessed, there is a tendency to focus on positive, measurable, and direct economic impacts (Fisher 2011), whereas consideration of socio-cultural impacts is marginal (Glasson et al. 2012). In the case of South Africa, du Pisani and Sandham (2006:707) suggested that SIA practice is "neglected" and "not yet on a sound footing," and can still be considered the =orphan' of EIA (Hildebrandt and Sandham 2014). Although there is clearly an ongoing debate regarding the relationship between SIA and EIA, we take the view that assessment of socioeconomic impacts is integral to EIA, and therefore the domain of the EIA practitioner is the social-ecological system (SES) that the development proposal may potentially have an impact on.

Social-ecological systems can be viewed as a nested hierarchy of geographical, physical, biological, social, economic, and cultural subsystems that interact interdependently and at different temporal and spatial scales, and wherein some of the interdependent relationships with humans are mediated through interactions with ecological units (Walker et al. 2002, Anderies et al. 2004, Ostrom 2009). They are, therefore, complex and multidimensional, and despite often forming the subject matter of environmental assessments, are often considered from a reductionist/rationalist perspective in EIAs (Lawrence 2000, Cashmore 2004, Bond and Morrison-Saunders 2011). Pope et al. (2013) acknowledged emerging opportunities for EIA practice lie in the further incorporation of concepts such as system dynamics, resilience, and ecosystem services into impact assessment. We seek to contribute to this debate and we suggest that EIA practice could benefit from incorporating evolving theory in the SES and 
complex systems literature, in particular, Anderies et al. (2004), Ostrom (2007, 2009), and Binder et al. (2013). We modify and extend these approaches and link them to an ecosystem services framework in proposing a methodology that can be used to characterize SESs and their susceptibility to impacts.

We first review international expectations in relation to the consideration of SESs in EIA, before discussing the particular requirements of South African legislation. The conceptual basis for the approach is then presented, following which we describe its preliminary application to a proposed estuary development. Because we wished to examine transferability of the approach, we also report on its application to a proposed mixed-use, rural agricultural project.

As far as we are aware, our study constitutes the first attempt to apply and formalize SES constructs to EIA practice within a regulated procedure. Our framework goes beyond conventional scoping approaches reliant on checklists and matrices, by requiring the EIA practitioner to cocreate a conceptual model of the current and future social-ecological system with the implicated communities. This means social and biophysical impacts are assessed integratively, and that communities participate meaningfully in the EIA process, thereby addressing two of the most common shortfalls of EIA practice. Recent EIA reviews call for EIA practice to include ecosystem services thinking and to also move toward more complete sustainability assessment (Morrison-Saunders and Retief 2012). Our framework provides a mechanism for doing so.

\section{Social-ecological systems (SES) and environmental assessment practice}

Given the patchwork evolution of EIA processes globally, it is not surprising that there is significant variation in the extent to which social impacts are explicitly acknowledged and assessed. In the USA for example, the scope of impacts covered by the National Environmental Policy Act (NEPA) is relatively broad, e.g., changes in land-use patterns, conflicts with land-use plans/ policies, impacts on historical and cultural quality, and socioeconomic and environmental justice. Implicitly therefore, investigation of coupled social-ecological systems is intended. In contrast, biophysical, including architectural and archaeological, impacts are emphasized in the European directive, but social and economic impacts are not specifically included (Wood 2003), and consequently consideration of socioeconomic impacts in Europe has had a lower profile (Glasson et al. 2012). Despite holistic consideration of impacts being implied in U.S. policy, the biophysical bias of early EIA is cited as a reason for the development of SIA in the late 1970s and early 1980s (Taylor et al. 2004).

For some time however, SIA has been regarded as secondary to EIA (Glasson and Heaney 1993, Burdge 2002, Chadwick 2002), and recent reviews suggest that there is still some way to go in relation to the effective integration of social and biophysical impacts (Fisher 2011, Hildebrandt and Sandham 2014). Pope et al. (2013:1) refer to "an apparently ever-increasing number of distinct and specialized forms of practice," and that the "plethora of specialist branches is generating a somewhat confusing picture and a lack of clarity regarding how the pieces of the impact assessment jigsaw puzzle fit together." It could be argued that this diversification of practice, in part, reflects practitioners' struggle in effectively dealing with SESs. At the very least, "the prevalence of these other forms of impact assessment suggest inadequacies (perceived at least in some quarters) in EIA practice, and a need to balance ex ante assessment" (Bond et al. 2012:53).

Sustainability assessment has been referred to as the third generation of impact assessment after EIA and SEA (Bond et al. 2012) and Morrison-Saunders and Retief (2012:35) acknowledge the "increasing demand internationally that EIA should move more toward sustainability assessment." Why this is relevant is that of all the practice areas, sustainability assessment would presumably require most explicit consideration of socialecological systems because one of its core principles is socialecological system integrity (Gibson 2006).

Hacking and Guthrie (2008) presented a framework that conceptualizes environmental impact assessment practice as a three-dimensional space along three axes of integratedness, strategicness, and comprehensiveness (see Fig. 1 for definitions).

Fig. 1. The difference between current and desired environmental impact assessment (EIA) practice in South Africa (adapted from Hacking and Guthrie 2008).

COMPREHENSIVENESS: whether the focus is narrowly biophysical or a more holistic conception, including the three pillars of sustainable development, i.e., environmental, social, and economic, and related impacts, as well as indirect effects. We define comprehensiveness to refer to the six aspects of the environment defined in the South African legislation, i.e., geographical, physical, biological, social, economic, and cultural.

STRATEGICNESS: refers to the goal of the assessment, e.g., avoiding negative impacts or also enhancing positive impacts, the width of the spatial and temporal coverage, and consideration of alternatives, cumulative impacts, and uncertainty.

INTEGRATEDNESS: refers to the extent of integration of: (1) techniques within the assessment process, e.g., is social impact assessment (SIA) undertaken on its own, as a component of EIA, in parallel with EIA, or as part of an integrated social and environmental impact assessment; and/or (2) the integration of themes covered by the assessment process, e.g., biophysical and social.

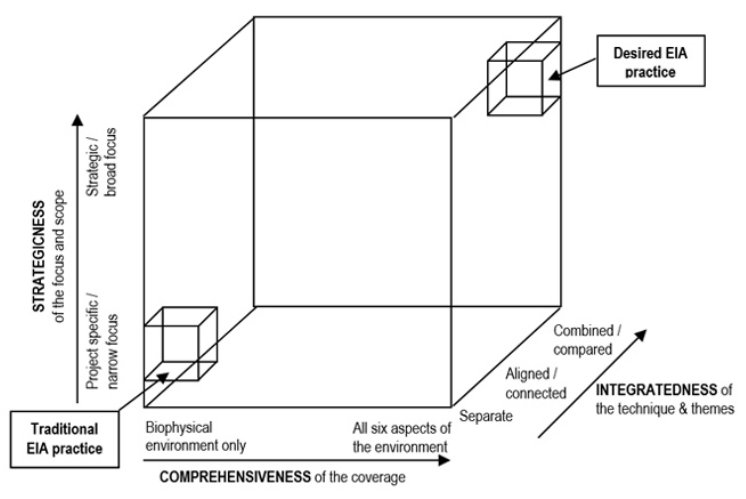


This framework is important in that it helps resolve some semantic issues associated with the proliferation of terminology and practice, and also provides a trajectory for moving from traditional biophysical EIA to a more comprehensive, integrated, and strategic sustainability assessment. The need for the latter in South Africa has recently been emphasized (Morrison-Saunders and Retief 2012), and we adapt the Hacking and Guthrie (2008) framework (Fig. 1) to illustrate the difference between present and desired practice in South Africa.

In the case of South Africa, it is clear that comprehensiveness is intended in the environmental assessment legislation (du Pisani and Sandham 2006). Thus regulations of the National Environmental Management Act (NEMA; Act 107 of 1998, Government of South Africa 2010) require that an EIA must include assessment of the six different components of the environment, i.e., geographical (spatial), physical, biological, social, economic, and cultural. Somewhat uniquely for environmental legislation, NEMA includes a set of principles requiring that "the social, economic and environmental impact of activities must be considered, assessed and evaluated and decisions must be appropriate in the light of such consideration and assessment." Morrison-Saunders and Retief (2012) have suggested that relative to the Gibson (2006) principles for sustainability assessment, in which social and ecological are firmly combined, NEMA arguably tends to treat the social, economic, and environmental components separately. Nevertheless, the complex nature of these systems is recognized in NEMA, "environmental management must be integrated, acknowledging that all elements of the environment are linked and interrelated, and it must take into account effects of decisions on all aspects of the environment and all people in the environment." Clearly there is an explicit legal requirement for the EIA process in South Africa to include integrated assessment of social impacts (du Pisani and Sandham 2006), and by implication, address the complexities of SESs.

The final axis of Figure 1 relates to the strategic focus. Although this refers to whether the assessment adopts a project-only focus or a more regional focus, it also relates to consideration of cumulative and secondary impacts, often only obvious if the scope of the assessment is broader. This axis is perhaps the most challenging, requiring a balance between obtaining sufficient detail, which allows for an increased strategic focus, without wasting unnecessary resources to obtain unnecessary detail. In principle, the initial scoping phase of an EIA is intended to identify the potentially important impacts from issues of less direct relevance (Glasson et al. 2012). The subsequent and detailed EIA phase then investigates these impacts and attempts to quantify them and assess their significance. Inadequate scoping can clearly lead to impacts not being identified, or alternatively not being addressed at the correct level of detail. Stirzaker et al. (2010:600) proposed the concept of "requisite simplicity" to help negotiate complex problems, defining it as "an attempt to discard some detail, while retaining conceptual clarity and scientific rigor, and which helps us move to a new position where we can benefit from new knowledge." The scoping process in EIA should therefore attempt to identify these requisite simplicities. This is also important because the financial implications of regulatory EIA compliance, relative to development needs, is strongly politicized, particularly in countries such as South Africa (Morrison-Saunders and Retief 2012).
There is the expectation therefore, that EIA practice would be located more toward the top right corner of the Hacking and Guthrie (2008) framework (Fig. 1), rather than the origin in which traditional biophysical EIA is located. Morrison-Saunders and Retief (2012:37) have reviewed the South African EIA legislation in relation to sustainability principles and have concluded that South Africa has a "strong and explicit sustainability mandate," and therefore the debate on the integration of sustainability into EIA should address "effectiveness of practice" rather than the legal mandate, highlighting the need for practitioners to innovate and embed sustainability thinking into their practice. We suggest our framework would help practitioners achieve this.

Environmental impact assessment (EIA) policy and practice in South Africa - bridging the social-ecological system (SES) hiatus In reality there is a significant hiatus between policy and practice because EIAs in South Africa frequently do not fully consider all environmental aspects (Hacking and Guthrie 2008, Sandham and Pretorius 2008, Kidd and Retief 2009, Morrison-Saunders and Retief 2012). Nor do EIAs generally take into consideration the linkages between the different environmental aspects. An example of a linkage could be how changes to the ecological environment will have an impact on the social environment, e.g., crafters who use estuary resources to make goods to sell can suffer a loss of crafting material, as a consequence of a proposed development like the damming of a watercourse to create a dam to irrigate new pastures. Morrison-Saunders and Retief (2012) highlighted that these indirect costs, often relating to ecosystem services and impacts on quality of life, pose difficulties in quantification and often extend over long timescales. Despite these being fundamental questions in any sustainability-focused EIA, they are often poorly resolved and may lead to poor decisions being made. In South Africa, and in other developing countries, examples include the construction of community halls and craft markets, which remain unused because of their unsuitable location or function, and as a result of inadequate assessment before commissioning (Riddell 2008). We suggest that development failures such as these are symptomatic of a failure to understand complex SESs.

There are at least two reasons for this hiatus in practice. First, in South Africa, EIAs are conducted by environmental assessment practitioners (EAPs), many of whom enter EIA practice with a natural sciences academic background (du Pisani and Sandham 2006, Hildebrandt and Sandham 2014). This has led to ecologically-focused EIAs, which generally consider biophysical aspects in isolation, without taking into account socioeconomic impacts, or the linkages between the different aspects (du Pisani and Sandham 2006). When social or economic impacts are included in these assessments, they are often appended to the report and are not integrated into the actual impact assessment (Burdge 2003, Barbour 2007, Hildebrandt and Sandham 2014).

Second, we argue that there is a lack of a systematic framework in which complex SESs can be described, understood, and investigated in an integrated manner during an EIA. Conventional approaches to scoping include checklists and matrices, and although these are useful and widely used (Canter 2008, Glasson et al. 2012), we argue that they have recognized shortcomings. Without a framework that is oriented toward holistic understanding of an SES, it is, for example, difficult to predict the consequence of land-use change on the flow of 
ecosystem services and sometimes even more difficult to communicate these impacts to affected communities. Clearly an approach, which helps map out interrelationships and interdependencies in SESs, while also providing a means of assessing and communicating impacts, would be of significant value to help improve practice in South Africa and other developing countries.

A final area of acknowledged weakness in EIA practice globally is that of meaningful public participation (Esteves et al. 2012, Morgan 2012, Pope et al. 2013). In South Africa, du Pisani and Sandham (2006:719) described that this is especially the case, and that EIA practice has "serious shortcomings" and that it should be redesigned to be more effective and "truly participative," although recent improvement is recognized (Hildebrant and Sandham 2014).

\section{CONCEPTUAL BASIS FOR THE FRAMEWORK}

\section{Current tools - matrix and network approaches}

Tools for identifying impacts range from simple checklists, through to matrices, networks, and quantitative methods (Morris and Therivel 2009, Glasson et al. 2012). These are intended to provide a more structured way of identifying impacts, as opposed to an ad hoc approach (Barrow 1997). Of these, matrices are probably the most well known for attempting to capture more complex relationships (Canter 1996). Rudimentary matrices are twodimensional charts showing components of the development on one axis and components of the environment on the other. More sophisticated magnitude matrices attempt to quantify this through a subjective assessment of components of the impact, e.g., magnitude, significance, or time frame (Glasson et al. 2012). Of these, the Leopold Matrix (Leopold et al. 1971) and the Peterson Matrix (Peterson et al. 1974) are the most widely used.

The qualitative Leopold Matrix consists of 100 columns representing the various activities, e.g., construction, water supply, associated with a project, and 88 rows representing the various environmental components to be considered. Environmental factors are divided into three groups: physical conditions, e.g., soil; biological conditions, e.g., fauna; and social and cultural conditions, e.g., land use. The matrix is completed to indicate the magnitude (from -10 to +10 ) and the importance (from 1 to 10) of the impact of each activity on each environmental factor (Leopold 1971, FAO 1996, Kassim and Williamson 2005, Glasson et al. 2012).

The Peterson Matrix (Peterson et al. 1974) is an extension of the concept and is a weighted impact interaction matrix (Noble 2009). This consists of three component matrices: (1) project impact against environmental components, (2) impacts of environmental change on the human environment, and (3) the relative importance of the human components. The approach uses the multiplication properties of matrices to find the effect of the casual elements on the human environment, whereas the resulting product is weighed according to the significance of the human impact (Noble 2009, Akintunde and Olajide 2011).

The Sorensen Network (Sorensen 1971) was the first network approach developed for use with EIAs (Turnbull 1992, Glasson et al. 2012) and is probably the best-known approach for investigating higher order impacts (Modak and Biswas 1999), although originally developed to help planners reconcile conflicting land uses in California (Glasson et al. 2012). Six environmental components, i.e., water, climate, geophysical conditions, biotas, access conditions, and aesthetics, are recognized, and the network's implementation begins with the practitioner identifying potential causes of environmental change associated with a proposed development, using a matrix format (Glasson et al. 2012). The first change in the environment is called an initial condition change, e.g., residential development. This initial condition change will affect other environmental components, termed consequent conditions, e.g., increased erosion caused by cleared vegetation on development footprint (Turnbull 1992).

Although these approaches are demonstrably relevant in EIA practice, they have limitations (Bojórquez-Tapia et al. 1998), and we suggest, particularly, with respect to their inability to deal with highly integrated and complex SESs (Table 1). So what can SES theory offer EIA? The first point relates to the value of conceptualizing, and then formally describing an SES in relation to its structural properties. Once a conceptual model is formalized, this enables a more structured and systematic process of examining the interactions between components and helps define the key issues and focus subsequent investigations.

\section{Methodological approach}

Anderies et al. (2004) presented a framework for disaggregating the components of an SES in a way that promotes the identification of critical linkages, and importantly, the potential vulnerabilities of SESs to disturbances. The latter makes this approach particularly appropriate in the context of impact assessment. The system is represented as comprising four components: (1) the resource system, (2) the resource users, (3) public infrastructure, and (4) public infrastructure providers (Fig. 2 ). This approach is strongly conceptually related to the SES framework of Ostrom $(2007,2009)$ in which the SES is described in terms of (1) resource system, (2) resource units, (3) users, and (4) governance system. In a recent comparison of frameworks for analyzing SESs, Binder et al. (2013) highlighted Ostrom's (2007, 2009) as being of particular value in that it was the only framework giving equal depth to social and ecological systems. In using Anderies et al. (2004) rather than Ostrom (2007, 2009), we retain this benefit while also emphasizing the infrastructural dimension that is common to almost all EIA projects.

Anderies et al. (2004) defined resource system as the geographical, biological, and natural physical environment. We define the resource system more specifically as an ecosystem (or ecosystems) comprising particular habitats, i.e., analogous to the resource system plus the resource units defined by Ostrom (2007, 2009), and delivering a suite of ecosystem services. The users are those that might be directly dependent on these ecosystem services, i.e., fisherman, or those further afield but who nevertheless derive benefit.

Public infrastructure refers to both built infrastructure, e.g., roads, buildings, and also social infrastructure, meaning the social networks and rules used by those governing, managing, and using the system, as well as those factors that affect monitoring and enforcement of those rules, otherwise referred to as social capital (Costanza et al. 2001, Ostrom and Ahn 2003) and governance system in the Ostrom $(2007,2009)$ framework. Having defined a conceptual model of the system, it is then possible to consider impacts to the system. These may be external disturbances to any 
Fig. 2. Adaptation of the Anderies et al. (2004) framework.

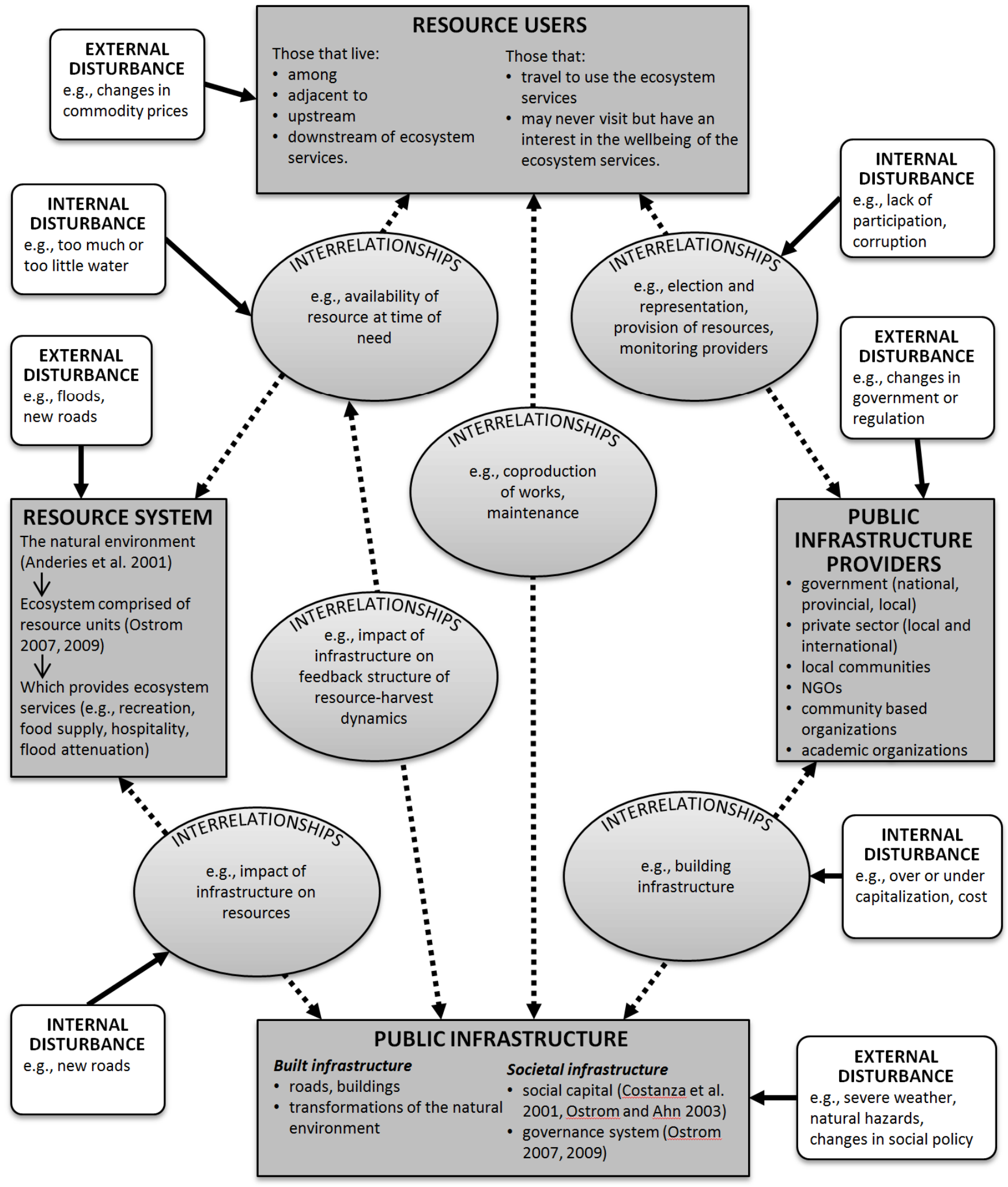


Table 1. Limitations of the Leopold Matrix, Peterson Matrix, and the Sorensen Network when dealing with complex social-ecological systems (SESs).

\begin{tabular}{ll}
\hline \hline General Limitation & Specific Comments \\
\hline Lack of transferability & $\begin{array}{l}\text { Leopold Matrix requires amendments for every project, can be too detailed for some projects, and not precise enough for } \\
\text { others (FAO 1996, Barrow 1997, Glasson et al. 2005). }\end{array}$
\end{tabular}

Time consuming, thus expensive

Physical-biological environment bias

Difficulties in applying to socioeconomic impact assessments

Concerns that key issues, particularly human, may be overlooked

Discrimination between a system's current and future state

Utility in public participation

Scoring poses subjectivity questions and has higher knowledge requirements

Accommodating qualitative and quantitative data

\section{Accommodating} quantification of impacts and their significance

Dealing with uncertainty and impact likelihood

Accommodating indirect, temporary, and long-term impacts
Leopold Matrix includes 8800 possible interactions and two entries per interaction, thus 176,000 items must be taken into account in decision making (FAO 1996, Wood 1999, Kassim and Williamson 2005).

Sixty-seven of the 88 environmental characteristics in the Leopold Matrix are biased toward the physical-biological environment (Kassim and Williamson 2005).

Sorensen Network is "reputedly difficult to apply...to socio-economic impact assessment” (Barrow 1997:145).

Leopold Matrix does not include a mechanism for focusing attention on the most critical human issues (Kassim and Williamson 2005). Likewise, the Sorensen Network presents over-simplification of a situation, which may result in key impacts being overlooked.

Because there is a high number of variables to consider with both matrices and the network, it is difficult to get an overview of the impacts (Barrow 1997, Noble 2009).

Because results are summarized on a single diagram, interactions may be perceived to have taken place (Kassim and Williamson 2005)

In matrix approaches there is a tendency for the structure of the system to be determined by the form of the matrix used.

There is substantial opportunity for double counting with the Leopold Matrix (Kassim and Williamson 2005).

Conventional matrix approaches are not aimed at identifying stakeholders (Kassim and Williamson 2005). The Leopold Matrix "does not facilitate public involvement" (Barrow 1997:140).

The scoring, and thus the outcome of the EIA, is entirety based on the subjective judgment of the scorers, because the tools do not provide explicit criteria for assigning numerical values to the weighting (Glasson et al. 2005, Kassim and Williamson 2005).

Network approaches demand "greater knowledge and expertise for their effective use" (Wood 1999:78).

Although the Leopold Matrix accommodates both quantitative and qualitative data, it does not discriminate between them (Munn 1979, Kassim and Williamson 2005).

Accuracy of the tools is limited by the adequacy of the data available and by the level of knowledge of the practitioner (Glasson et al. 2005).

Sorensen Network identifies impacts but does not establish their magnitude, significance, or extent of change (Barrow 1997).

Matrix approaches do not incorporate details of the methodology/technology used to predict impacts (Glasson et al. 2005).

There is no provision for indicating uncertainties resulting from inadequate data or knowledge in both the matrix and network approaches. All predictions are treated as if certain to occur (Kassim and Williamson 2005).

Matrix approaches do not specify the probability of an impact occurring (Glasson et al. 2005).

Neither cater for indicating environmental variability, including the possibility of extreme, unacceptable hazards, nor are the associated impact probabilities indicated (Kassim and Williamson 2005).

Matrix approaches are unable to identify significant indirect, secondary, or cumulative impacts (Wood 1999).

Although the Sorensen Network can identify indirect impacts, it is restricted to third and lower order impacts (Modak and Biswas 1999). 
Matrix approaches and the Sorensen Network (Ogola 2007) are unable to identify and handle temporary aspects.

Leopold Matrix does not distinguish between immediate and long-term impacts (Kassim and Williamson 2005).

Matrix approaches do not relate environmental components to one another, so the complex interactions between the different components, which lead to indirect impacts, are not assessed (Glasson et al. 2005).

Consideration of alternatives Users may sum the numerical values to produce a composite value to compare with that of other developments or
alternatives, but since the matrices do not assign weighting to different impacts to reflect their relative importance, it would
not be possible to compare the impacts associated with different developments or alternatives (Glasson et al. 2005).
Accommodating mitigation and monitoring measures
The magnitude of the predications with the matrix approaches are not related explicitly to the 'with-action' and 'withoutaction' future states (Kassim and Williamson 2005).

Matrix approaches have no capability for making recommendations on inspection procedures to be followed after completion of a project (Kassim and Williamson 2005).

or all the four components of the system, whereas internal disturbances are interactions between one or more of the components. Figure 2 provides examples of these and illustrates the value of both representing the structure of the SES and using interrelationships to reveal potential issues, impacts, and problems.

We have further refined the approach of Anderies et al. (2004) by defining the resource system in ecosystem services terms. This is important because it both provides a basis for quantification and retains the interdependencies between ecosystems and the socioeconomic environment. Incorporation of ecosystem services into EIA is acknowledged as an emerging opportunity in EIA theory and practice (Pope et al. 2013), and although Baker et al. (2013) concurred, they also argue for further practical application to help foster debate and incorporation into practice. The final aspect of our contribution is that we have integrated this process with the South African EIA procedure; the result is what we will refer to as the Social-Ecological-System Environmental Assessment (SES-EA) framework (Fig. 3).

\section{Methodology}

We developed and applied the SES-EA framework to proposed accommodation development in a rural estuary setting in the Eastern Cape Province, South Africa. The estuary is a tourist destination because it is relatively unspoilt and offers a variety of recreational activities. This development would require EIA authorization, and therefore the use of our framework in this context provided some insight into its potential utility as an EIA tool. The estuary is also important to local people who use it directly in maintaining their livelihoods (Bowd et al. 2012). Following development and application of the method in this case study, we tested the transferability and utility of the SES-EA framework in a proposed wine estate development in the KwaZulu-Natal Midlands of South Africa.

Application of the framework requires a participative approach to coproduce understanding. For the estuarine project, workshops were held with stakeholders, i.e., resource users and public infrastructure providers, on 28-29 October 2008 and 17-18 March 2009. For the wine estate project, public meetings were held on 16 July 2009 and 30 July 2010 for all interested and affected parties.

\section{DEVELOPMENT AND APPLICATION OF THE SOCIAL- ECOLOGICAL-SYSTEM ENVIRONMENTAL ASSESSMENT (SES-EA) FRAMEWORK}

The SES-EA framework comprises three phases (Fig. 3), which relate both to the generic EIA process (Glasson et al. 2012), but also to the statutory South African EIA procedure. The first phase aims to both define the resource system and the resource users; this constitutes the boundary of the SES. The second phase is aimed at developing an understanding of the SES, in particular the complex set of interrelationships, and the potential issues and impacts associated with the proposal. Because the six aspects of the environment are explicitly included in the conceptual model of the SES, this means they must necessarily be considered from the start.

\section{Phase 1: defining the boundaries of the social-ecological system} (SES)

The identification of the boundaries of an SES requires the consideration of the resource system, i.e., the geographical (spatial), biological, and natural physical environment, and the resource users, i.e., the social systems (stakeholders) deriving benefits from the resource system (Anderies et al. 2004). Boundaries are determined by both identifying the different habitats within the resource system (Step 1) and the ecosystem services supplied by these habitats (Step 2).

For the estuary case study, ecological habitats included mangroves, reedbeds, salt marshes, and water surface. In addition, the estuary basin, i.e., the area of the landscape that drains directly into the estuary, featured grasslands, forests, and streams. Adjacent coastal habitats, e.g., beaches, can also be viewed as an integral part of the estuary's ecological system. Estuary-linked ecosystem services supplied by the different habitats included food provision, hospitality, recreation, and flood attenuation (Bowd et al. 2012). To enable these services to be derived from the habitats of the ecological system, transformations, e.g., bridges, roads, buildings, harvesting nets, and ploughed fields, need to have occurred. Step 3 thus focuses on identifying the transformations that have occurred, or need to occur, to establish or maintain the desired supply of ecosystem services.

The final step is identification of the different users of these ecosystem services, and in particular those upon whom the proposal may have an impact. Resource users can originate from 
Fig. 3. The social-ecological system environmental assessment (SES-EA) framework. Refer to Figure 2 for estuarine examples of the resource system, resource users, public infrastructure, and public infrastructure providers. *Any transformations identified in Phase 1 , step 3 must be included. ** Identify whether the public infrastructure providers are resource users.

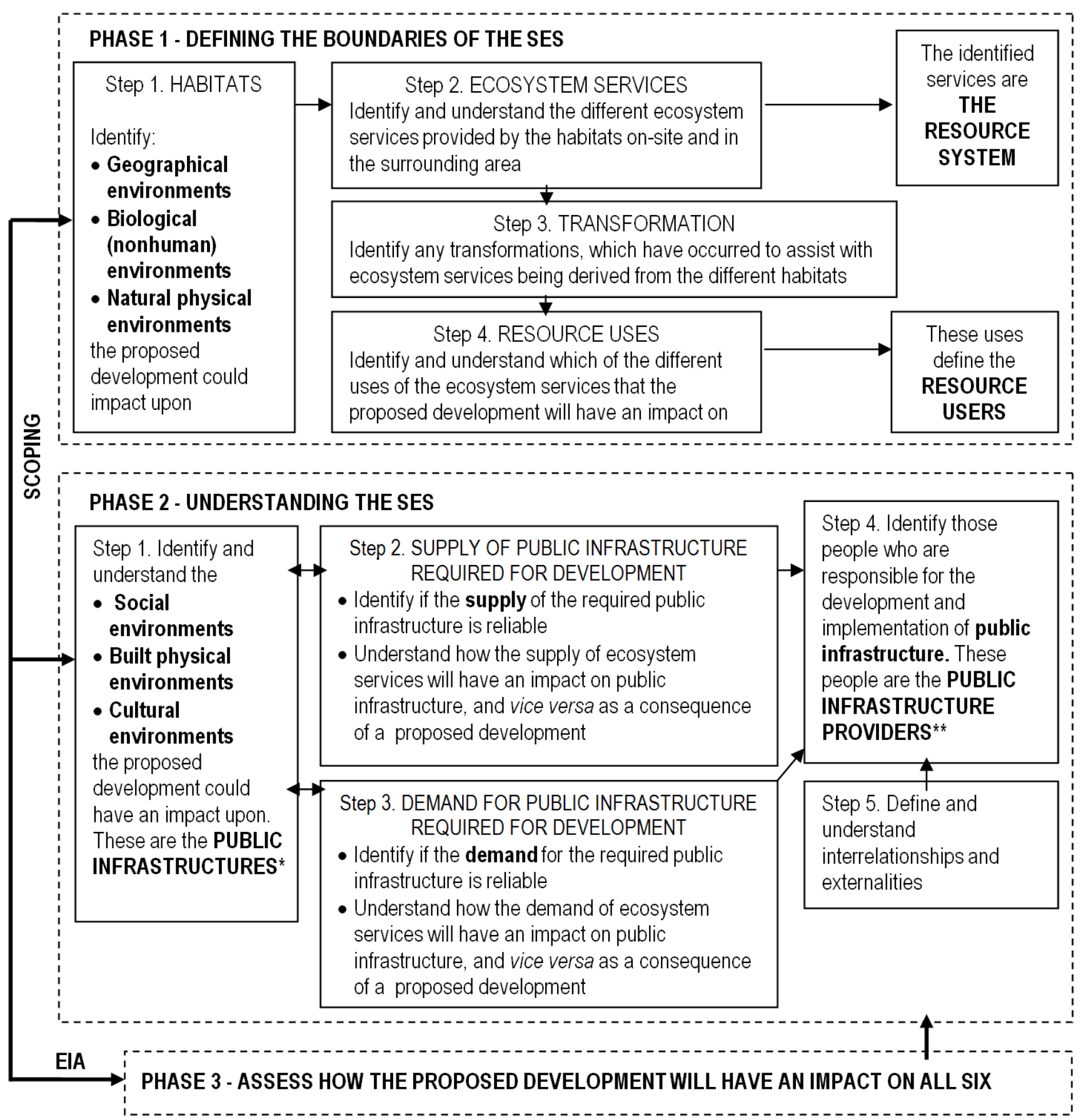

*Any transformations identified in Phase 1, step 3 must be included.

** Identify whether the public infrastructure providers are resource users. 
a wide range of locations and can influence and/or are influenced by the ecosystem services supplied by the system. For example, local residents, tourists, neighboring communities, farmers, fishermen, and nongovernment organizations (Bowd et al. 2012). We identified six proximity-based categories of resource user (Fig. 2).

\section{Phase 2: understanding the social-ecological system (SES)}

The objective of the first step in this phase is to identify and understand the public infrastructure, that is to say the built physical environment, including the transformations already identified, as well as the social and cultural environments. Public infrastructure enables a resources user to use a resource and consists of all social and economic capital associated with an SES, and can come in a variety of different forms. For our case, study we identified seven different categories of infrastructure (Table 2).

The second and third steps in this phase relate to the supply and demand of public infrastructure, respectively. First, one examines whether the supply of public infrastructure is reliable and what the impacts of proposed development might be and vice versa. Second, one needs to consider the demand for public infrastructure. In other words what public infrastructure is needed to maintain the current supply of ecosystem services, but also in relation to the proposed development. In our view, approaching things from this perspective is useful in the identification of alternatives, a key requirement of most EIA systems internationally.

Step 4 identifies those who are responsible for the development and implementation of public infrastructure, i.e., the public infrastructure providers. The list of different public infrastructure types (Table 2) can be used to help identify the different groups of public infrastructure providers. It is also useful to refer to the list of resource users because these can be the same people. In this way, additional relevant stakeholders are identified, again an essential part of scoping in most EIA systems.

In identifying the resource system, the resource users, the public infrastructure, and the public infrastructure providers, the practitioner has developed an integrated conceptual model of the SES. This model includes the key actors, i.e., stakeholders, and identifies the critical resources underpinning their interaction. The final step in this phase is to systematically explore these interrelations by way of a structured SES matrix (Table 3), representing the interlinkages shown in Figure 2.

Table 3 demonstrates the nature of the possible relationships that may be operating among the four components of the system, together with estuarine examples. Also included in this matrix are the external biophysical, social, and economic forces that may generate perturbations in the local system. The SES matrix must be interpreted by how the components in the rows have an impact on the components in the columns.

\section{Phase 3: impact assessment}

Whereas phases 1 and 2 typically represent scoping, phase 3 corresponds to the traditional impact assessment stage, i.e., the definition and significance of impacts, during which other EIA tools, such as the rapid impact assessment matrix (RIAM) (Pastakia and Jensen 1998) and the cumulative effects assessment (CEA; Smit and Spaling 1995) could be used. Incorporation of ecosystem services into EIA procedure is being emphasized in the literature (Baker et al. 2013, Partidario and Gomes 2013), and because our definition of the resource system is in relation to the ecosystem services provided, this could constitute a basis for achieving this.

\section{TRANSFERABILITY OF THE SOCIAL-ECOLOGICAL- SYSTEM ENVIRONMENTAL ASSESSMENT (SES-EA) FRAMEWORK}

To test transferability, the framework was applied to an agricultural site in rural KwaZulu-Natal, located $12 \mathrm{~km}$ from the nearest major town and $25 \mathrm{~km}$ from a major city. The KwaZuluNatal Midlands is known for its tourist route, whereby enterprises have become established, e.g. leather work, gourmet foods, and tourist accommodation. There are a number of current and proposed townships, government housing for the poor, within a five $\mathrm{km}$ radius of the development site. Only $30 \%$ of the local population is employed, which is predominantly linked to agriculture and tourism. The development site is 50 ha in extent and currently comprises a farmhouse and $300 \mathrm{~m}^{2}$ of commercial land use, i.e., restaurant and tourist shops. The site has been transformed through a combination of past and current farming and associated retail operations. Surrounding land use is predominantly agricultural, consisting of wattle plantations, grazing, and seasonal vegetables.

The development proposal comprises the establishment of a residential wine estate consisting of: 20 high-income residential units; expansion of an existing commercial node to $3000 \mathrm{~m}^{2}$; expansion of vines from 5 ha to 35 ha; establishment of a winery; and upgrading of existing infrastructure, e.g., internal road network, water and electricity supply. It is therefore a mixed-use (residential/agri-business) proposal.

Table 4 shows the results of implementing the SES-EA framework for the development, arranged in relation to the stages of the SESEA process. The results show how the ecosystem services provided by the habitats, e.g., enhancing the water quality of runoff flowing through the onsite wetland system, can have an impact on the SES, e.g., the runoff feeds into the main water supply dam for the area. The framework aided in the identification of past transformations within the SES that could have a negative impact, e.g., adjacent poultry farm has the potential to emit nuisance odors, or have a positive impact, e.g., good electricity supply, on the proposed development. Beyond what is likely to have been achieved with a normal scoping assessment, the framework aided in building, together with stakeholders, an overall conceptual understanding of the site, its linkages within the broader landscape, and its provision of ecosystem services under current and future scenarios. A further benefit was the identification of required infrastructure, e.g., water provision, local road network, effluent disposal, and identification of who may be responsible for its supply and maintenance. In addition, the framework helped gain an understanding of the relevant resource users, e.g., tourists and local farmers, and highlighted potential conflicts associated with the establishment of the proposed development, e.g., concerning sense of place.

As was the case with the estuary case study, one identified potential impact was accelerated deterioration of the local road networks. In response to this, the framework helped identify that discussion with the Roads Department was required to ensure 
Table 2. The seven different types of public infrastructures with examples from an estuarine case study, which considers the establishment of a community-based accommodation facility linked to a currently established hotel.

\begin{tabular}{ll}
\hline \hline $\begin{array}{l}\text { Type of Public Infrastructure } \\
\begin{array}{l}\text { Transformation } \\
\text { infrastructure }\end{array}\end{array}$ & Description of Each Type \\
$\begin{array}{l}\text { Legal and regulatory } \\
\text { infrastructure }\end{array}$ & Laws in the form of acts, regulations, policy documents, and customary regulations \\
Institutional infrastructure & $\begin{array}{l}\text { Private/business structures, e.g., for trade between different businesses } \\
\text { Social structures, e.g., traditional practices relating to the use of natural resources } \\
\text { Government/political structures, e.g., structures to define powers and responsibilities }\end{array}$ \\
Knowledge infrastructure & $\begin{array}{l}\text { Indigenous/cultural knowledge, e.g., knowledge concerning the local uses of different natural resources } \\
\text { Scientific/technical knowledge, e.g., that relating to the condition of ecosystems }\end{array}$ \\
$\begin{array}{l}\text { Skills infrastructure } \\
\text { Communication } \\
\text { infrastructure }\end{array}$ & $\begin{array}{l}\text { The skills of those involved in each type of infrastructure } \\
\text { Transportation, e.g., via vehicle }\end{array}$ \\
Relationship infrastructure & $\begin{array}{l}\text { Telephonic/digital communication } \\
\text { The relationship among and between all the different types of infrastructures }\end{array}$ \\
\hline \hline
\end{tabular}

continued maintenance of the local road network. Any additional costs could therefore be contextualized in relation to longer-term increases in economic activity and therefore a funding base to support road development and maintenance. This highlights the important aspect of secondary and cumulative impacts, which are not easily accommodated within conventional matrix-only type approaches.

In applying the framework, it became evident that the only controversial aspect of the proposal was the residential development component, because the agricultural aspect, i.e., winery and vines, and the commercial node were in keeping with the area and also complied with government planning policy, i.e., job creation and improvement of agriculture in agricultural areas. A number of stakeholders, most notably surrounding affluent land owners, were strongly against the residential development on the grounds of a potential impact on the sense of place. However, application of the framework also showed that revenues generated from the sale of the residential units was required to fund the agricultural and commercial components, without which the development would not occur. A trade-off could then be articulated between a potential negative change in sense of place and the positive impacts of the development as a whole. In the estuary case study, the SES-EA framework similarly enabled the identification of trade-offs between tourism and sand-winning and enabled stakeholders to engage in an informed discussion of these issues. In both cases, this would be an unlikely outcome using traditional EIA approaches.

\section{DISCUSSION}

Earlier we acknowledged the need for EIA practice to move toward sustainability analysis, represented in Figure 1 by increased strategic focus, comprehensiveness, and integration (Hacking and Guthrie 2008). Comprehensiveness means considering all aspects of the environment, whereas integration refers to the complex interrelationships and interdependencies that define socialecological systems. Clearly the extent to which the proposed framework enables understanding of these complexities is an important consideration in evaluating its utility and value in helping shift EIA practice toward sustainability assessment. A second weakness of EIA practice acknowledged earlier related to the effectiveness of public participation.
Does the proposed framework help to understand the interrelationships and interdependencies within a socialecological system (SES)?

To address this question we have used the five criteria proposed by Binder et al. (2013) for evaluating the effectiveness of SES conceptual frameworks (Table 5).

\section{Criterion 1: conceptualization of the social system and its} dynamics

This criterion refers first to the diversity of social, i.e., hierarchical, levels of the system, e.g., individual, group, or society, which are represented, and second, to the level of interaction across these levels, i.e., macro influence of governance system on individuals vs micro individual decision making and learning changes governance. The social system conceptualized within the SES-EA framework comprises individual resource users, communities, and public infrastructure providers, i.e., provincial and national government departments and their agents, and therefore accommodates all social levels. In relation to the degree of interaction, Binder et al. (2013) suggested better representation arises in a system in which individual behavior can influence the social structure and vice versa. The nature and scope of the development project will determine the combination of level and degree of interaction, but most projects will extend from the level of the individual through to society at large, and the framework permits the conceptualization of both the synchronic and diachronic duality between the micro and macro referred to by Binder et al. (2013). For example, as part of the coproduction workshop an individual, i.e., micro level, could propose a mitigation measure that would alleviate an impact, which in turn is incorporated as part of the conditions for project approval and thereby becomes part of the formal governance system, i.e., macro level.

\section{Criterion 2: conceptualization of the ecological system and its} dynamics

In this criterion, Binder et al. (2013) considered the conceptualization of the ecological system in relation to the two opposing paradigms; the anthropocentric versus the ecocentric. The SES-EA framework conceptualizes the dynamics of an ecological system from an anthropocentric perspective: the ecological system is regarded as a provider of services that 
Table 3. Social-ecological system (SES) matrix showing the linkages between the four main components of an SES, and how biophysical, social, and economic forces relate to the four different components. Estuarine examples of the linkages have also been provided. The 'resource' has been omitted as a row, because the external impacts generally have an impact on the resource, and this is addressed by the addition of 'biophysical forces' as an additional row.

\begin{tabular}{|c|c|c|c|c|}
\hline & Resource System & Resource User & Public Infrastructure & Public Infrastructure Provider \\
\hline \multicolumn{5}{|c|}{ Internal disturbances } \\
\hline $\begin{array}{l}\text { Resource } \\
\text { user }\end{array}$ & $\begin{array}{l}\text { The resource supplies } \\
\text { ecosystem services to the } \\
\text { resource users. } \\
\text { Overexploitation of these } \\
\text { services will have a } \\
\text { detrimental impact on the } \\
\text { resource system. }\end{array}$ & $\begin{array}{l}\text { Resource users can have } \\
\text { neutral, positive, and/or } \\
\text { negative relationships with } \\
\text { each other over use of the } \\
\text { resource system, e.g., } \\
\text { communities remove alien trees } \\
\text { for firewood and thus help } \\
\text { reduce alien vegetation. }\end{array}$ & $\begin{array}{l}\text { Used by the resource users and } \\
\text { can have both positive and } \\
\text { negative impacts on users, e.g., a } \\
\text { tourist enterprise may not } \\
\text { succeed if the access road is } \\
\text { frequently impassable. }\end{array}$ & $\begin{array}{l}\text { Generally provide public } \\
\text { infrastructure to meet the needs of } \\
\text { resource users, e.g., a municipality } \\
\text { may build a bridge to allow access } \\
\text { to an inaccessible place. }\end{array}$ \\
\hline $\begin{array}{l}\text { Public } \\
\text { infrastructure }\end{array}$ & $\begin{array}{l}\text { Available public } \\
\text { infrastructure has an } \\
\text { impact on the condition of } \\
\text { a resource system, e.g., the } \\
\text { tarring of a road could } \\
\text { have a negative impact on } \\
\text { an estuary, because it } \\
\text { could facilitate access, } \\
\text { resulting in intensive } \\
\text { fishing. }\end{array}$ & $\begin{array}{l}\text { Resource user activities and } \\
\text { allocation of resources are } \\
\text { influenced by the availability of } \\
\text { public infrastructure, e.g., the } \\
\text { implementation of Black } \\
\text { Economic Empowerment } \\
\text { (BEE) legislation creates } \\
\text { preferential access, and thus } \\
\text { opportunities, for historically } \\
\text { disadvantaged individuals. }\end{array}$ & $\begin{array}{l}\text { The implementation of one type } \\
\text { of public infrastructure may } \\
\text { detract from another type, e.g., a } \\
\text { public parking lot established } \\
\text { adjacent to an exclusive lodge } \\
\text { may have a negative impact on } \\
\text { an exclusive lodge. }\end{array}$ & $\begin{array}{l}\text { Potential new public infrastructure } \\
\text { is often influenced by the currently } \\
\text { available infrastructure, e.g., a hotel } \\
\text { chain may be more likely to } \\
\text { establish a new hotel if a tarred } \\
\text { road is previously established. }\end{array}$ \\
\hline $\begin{array}{l}\text { Public } \\
\text { infrastructure } \\
\text { provider }\end{array}$ & $\begin{array}{l}\text { Public infrastructure } \\
\text { providers can have both } \\
\text { beneficial and detrimental } \\
\text { impacts on the resource } \\
\text { system, e.g., a hotel could } \\
\text { monitor the water quality } \\
\text { of an estuary and take } \\
\text { rectification action if } \\
\text { required. However it } \\
\text { might be the hotel that is } \\
\text { polluting. }\end{array}$ & $\begin{array}{l}\text { Public infrastructure providers } \\
\text { do not always meet the needs } \\
\text { of all resource users. Conflict } \\
\text { can arise between what the } \\
\text { resource users and public } \\
\text { infrastructure providers want. }\end{array}$ & $\begin{array}{l}\text { The implementation of public } \\
\text { infrastructure is reliant on the } \\
\text { capacity and competency of the } \\
\text { public infrastructure providers, } \\
\text { e.g., there may be good policy on } \\
\text { solid waste disposal, but if the } \\
\text { municipality is not able to } \\
\text { implement it, solid waste will } \\
\text { remain a problem. }\end{array}$ & $\begin{array}{l}\text { Public infrastructure providers can } \\
\text { work together and against one } \\
\text { another. An example of the latter is } \\
\text { when one department is promoting } \\
\text { economic growth using } \\
\text { infrastructural development, and } \\
\text { another department is promoting } \\
\text { conservation. }\end{array}$ \\
\hline \multicolumn{5}{|c|}{ External disturbances } \\
\hline $\begin{array}{l}\text { Biophysical } \\
\text { forces } \\
\text { i.e., } \\
\text { biological, } \\
\text { nonhuman, } \\
\text { and natural } \\
\text { physical } \\
\text { forces }\end{array}$ & $\begin{array}{l}\text { External biophysical } \\
\text { forces have an impact on } \\
\text { natural resources. These } \\
\text { include droughts and } \\
\text { floods. These events can } \\
\text { change the quantity of } \\
\text { ecosystem services. }\end{array}$ & $\begin{array}{l}\text { There can be a negative impact } \\
\text { on resource users if they have } \\
\text { not considered fluctuations in } \\
\text { the supply of ecosystem } \\
\text { services. }\end{array}$ & $\begin{array}{l}\text { Biophysical forces can influence } \\
\text { public infrastructure, e.g., } \\
\text { natural disasters can cause wash- } \\
\text { aways and destroy } \\
\text { communications, limiting access } \\
\text { to enterprises and causing } \\
\text { financial losses. }\end{array}$ & $\begin{array}{l}\text { Public infrastructure providers can } \\
\text { be prepared or ill-prepared for } \\
\text { unexpected biophysical forces, e.g., } \\
\text { Roads Department may have } \\
\text { financial provisions for road repairs } \\
\text { after major flood events, knowing } \\
\text { that flooding was likely. }\end{array}$ \\
\hline $\begin{array}{l}\text { External } \\
\text { social and } \\
\text { economic } \\
\text { forces } \\
\text { i.e., social, } \\
\text { economic, } \\
\text { and cultural } \\
\text { forces }\end{array}$ & $\begin{array}{l}\text { External social and } \\
\text { economic forces can alter } \\
\text { the resource base, e.g., } \\
\text { poor people may over use } \\
\text { fish stocks, or affluent } \\
\text { people may displace poor } \\
\text { users, such as a fishing } \\
\text { concession excluding local } \\
\text { fishermen from previously } \\
\text { used sites. }\end{array}$ & $\begin{array}{l}\text { External social and economic } \\
\text { forces can influence resource } \\
\text { users. Conflict, crime, and } \\
\text { uncertainty can influence } \\
\text { changes in demand for local } \\
\text { services, e.g., dangerous driving } \\
\text { on access routes could } \\
\text { discourage tourists from } \\
\text { visiting. }\end{array}$ & $\begin{array}{l}\text { External social and economic } \\
\text { forces can have both positive } \\
\text { and negative impacts on public } \\
\text { infrastructure, e.g., if a new road } \\
\text { is established, it is likely to result } \\
\text { in increased accessibility. This } \\
\text { could result in increased tourist } \\
\text { facilities, which could cause } \\
\text { ground and surface water } \\
\text { pollution if their sewage systems } \\
\text { are not maintained. }\end{array}$ & $\begin{array}{l}\text { Delivery is reliant on social and } \\
\text { economic forces. Public } \\
\text { infrastructure providers must meet } \\
\text { performance requirements, e.g., a } \\
\text { municipality must demonstrate } \\
\text { sound fiscal management to attract } \\
\text { foreign investors, who could } \\
\text { provide investment for the area. }\end{array}$ \\
\hline
\end{tabular}

increases human well-being (Binder et al. 2013). This is at least consistent with the South African definition of sustainable development, which is "unashamedly anthropocentric" (Morrison-Saunders and Retief 2012:38). The boundaries of an SES are initially identified through the identification of ecological system boundaries. However the ecological system boundaries are determined based on whether or not a proposed development will or is likely to have an impact on this ecological system. The scale of the ecological system being assessed is related to the physical impacts of the proposed human development. However, the SES-EA does not facilitate consideration of the dynamics between the different ecological elements within an SES, but rather only the dynamics of the ecological system that are relevant to human well-being. 
Table 4. The results of applying the social-ecological system environmental assessment (SES-EA) framework to a development proposal for establishment of a residential wine estate in the KwaZulu-Natal Midlands, South Africa.

Phase 1: Defining the boundaries of the social-ecological system (SES)

Step 1. Habitat

Maize dominates the site (65\%); also vines (10\%), Acacia mearnsii (Black Wattle) and Eucalyptus grandis (Blue Gum) (10\%), Pennisetum clandestinum (Kukuyu Grass) (10\%), hardened surface (paving, concrete, roofing; 3\%), and aquatic habitats (wetland, 5000 $\mathrm{m}^{3}$ dam and stream; $2 \%$ ).

A natural aquifer traverses the site from east to west.

Step 2. Ecosystem services the resource system

The stream and aquifer supply a dam, which is the main water source for a major city located $25 \mathrm{~km}$ south of the development site.

The wetland system helps clean the stream water, which has elevated nutrient levels caused by intensive grazing upstream.

Bird life use the freshly cultivated maize lands for seasonal foraging.

The soils, despite having low percolation, are used to grow vines and maize, they provide good grazing land, and are suitable for construction.

Step 3. Transformation

A poultry facility on an adjacent property.

A borehole on the property extracts ground water from the aquifer and feeds the dam on-site, thereby increasing the connection between groundwater and surface water.

The site has suitable soils and topography for vines.

The soil type is not ideally suited to maize; however a maize company plants and fertilizes the site for advertising purposes, because of its location on the tourist route.

The farm house and tourism-linked commercial operations have associated gardens, access roads, parking areas, and septic tank and soakaway systems.

Step 4. Resource uses

If stormwater and effluent are not managed correctly, the stream, wetland system, and aquifer could become polluted, and in turn, pollute the dams on and off site.

Fertilizer application can increase nutrient load and sedimentation in the stream and wetland system. Although vines require fertilizer, a minimal amount is used in comparison to maize, thus the removal of the maize could potentially reduce nutrient inputs to the stream and wetland.

Maize supports a greater diversity of birdlife in comparison to vines, especially when the maize land is fallow. However indigenous gardens around the residential units can provide suitable foraging habitat for a wider variety of bird life all year round. An increased number of people have the potential to disturb bird life.

The application of vine biocides could have detrimental health implications for the residents.

Resource users

Downstream beef and dairy farmers use the stream to water their cattle.

Upstream farmers use the wetland to improve runoff quality.

Residents and visitors who appreciate the area for its sense of place.

On-site commercial shop owners and restaurant and farm house owner (same person).

Birders/local conservation group.

Downstream water users who use the main water supply dam, e.g., inhabitants of the major city.

Maize company who leases the land to grow maize for advertising purposes.

Phase 2: Understanding the social-ecological system (SES)

Step 1. Identifying and understanding the public infrastructure

Surrounding neighbors, i.e., farmers, enterprise owners, and tourists, who enjoy the area's agricultural sense of place are likely to oppose a 20-unit residential development, which has the potential to change the local sense of place. However, enterprise owners and tourists will benefit from the winery and increased commercial area.

There is a nearby township $(<5 \mathrm{~km})$ whose community has limited formal education and $\sim 70 \%$ unemployment.

Wine making is labor intensive. Those seeking employment would be supportive of this development.

Birders and conservation groups are likely to be against all development that could cause pollution and have a negative impact on wildlife.

Municipal water and sewage reticulation is not available. The municipality does not have the funds to connect the site to either service.

The area has a reliable electricity connection, and there is a good public road network.

The development will reduce unemployment, which may reduce crime; however criminals may be attracted to an affluent development

The poultry farmer may be apprehensive about receiving odor complaints from the new residence and tourists.

The maize company will no longer be able to use the site to advertise.

The development will help meet the demand for high-income homes in the area, and the additional commercial development will contribute to attracting tourists.

The additional vines and wine processing facility will promote local tourism and be a catalyst to other land owners who wish to diversify into another type of agriculture.

Step 2. Supply of public infrastructure

There is no municipal sewage reticulation and the soils on site have poor percolation rates. If effluent is not properly managed, it could have a detrimental impact on the aquatic habitats and the aquifer.

Municipal water is not available. The yield of the hole on site is not sufficient for the proposed development; however if supplemented from a borehole on an adjacent property, there will be sufficient water available.

There is sufficient and reliable power for the proposed development

The local public road network is generally well maintained. 
Step 3. Demand of public infrastructure

There is local demand for drinking water. If the development has an impact on the functioning of soil filtration or wetland system, this could have a negative impact on water supply.

The development is located within a water stressed catchment. Thus additional pressure on ground groundwater could reduce the availability of water for local agricultural activities.

Increased overhead power lines have the potential to increase bird fatalities.

Increased road usage, as a result of the development, will accelerate road deterioration.

Step 4. Public infrastructure providers

Developer to provide waste water treatment plant. The plant must treat effluent to agricultural standards, and infrastructure must be established to enable the treated effluent to be used for agriculture, e.g., irrigation onto vines.

Developer to provide water from borehole on property, and adjacent property owner to agree to servitudes over borehole.

Developer to extend power lines and local electricity company to provide power. Power lines must be placed underground to avoid bird fatalities.

The roads department is responsible for road maintenance.

Step 5. Understanding the economic environment

Developer is responsible for the majority of the public infrastructure, thus the developer will ensure that there are sufficient funds for the required public infrastructure before commencing with the development.

The profit from the units will fund the (1) expansion of the commercial operation; (2) additional 30 ha of vines; and (3) wine processing facility. Developer must obtain a written undertaking from the electricity company to supply electricity and the roads department to maintain the local road network.

Phase 3: Assess how the proposed development will have an impact on all six environments Economic

Large capital investment into the area through the establishment of 20 high-income residential units. The large capital injection will come into the local economy though job creation, increased visitor numbers and thus spending, increased municipal rates, and introduction of a new agri-industry to the area.

The maize company will no longer advertise on the site, which may result in reduced profits. However, given the agricultural nature of the area, it is likely that the maize company will be able to identify another suitable site in the area to advertise.

Cultural

There are no cultural sites on or near to the development site.

Physical

Built

The development will increase the built physical environment, by way of additional structures and service infrastructure. The Natural

development may have an impact on road quality.

Social

The development will have a limited impact on natural vegetation because the site is already highly transformed.

Employment associated with the development will improve the living standards of the local community.

Although poultry-associated odors could deter potential residents, chicks are removed at one day old, and this practice does not produce nuisance odors.

The development could result in other local properties growing vines, because there would be a local wine processing facility to process their crop.

Biological

The residential infrastructure will have a negative impact on those surrounding neighbors who enjoy the agricultural sense of place.

If the development have an impact on the functioning of the soil filtration or wetland system, this could have a negative impact on the main water supply for the area.

Maize removal could decrease the availability of foraging habitat for birds, however the establishment of indigenous gardens around the residential units may provide suitable foraging habitat for birdlife all year round. This may benefit conservation groups.

Geographical

Thirty hectares of vines will be established, and platforms will be cut for the establishment of 20 residential units and the expansion of the commercial facility.

\section{Criterion 3: conceptualization of the interaction between the} social and the ecological systems

Binder et al. (2013) referred to whether the ecological system influences the social system $(\mathrm{E} \rightarrow \mathrm{S})$, human activities affect the ecological system or ecosystem services $(S \rightarrow E)$, or whether the framework permits evaluation of reciprocity between the social and ecological systems, as indicated by the bi-directional arrow $(\mathrm{E} \leftrightarrow \mathrm{S})$. The SES-EA framework conceptualizes the interactions between the social and the ecological systems as how a proposed development will affect the ecological system by way of reducing the services the ecological system can provide to the social system. However, the framework does not explicitly promote the consideration of how a development may have an impact on or between ecological subsystems. Furthermore, both social and ecological systems are dynamic and will change over time. The framework helps define the present SES and so promotes the consideration of impacts on the current state rather than future social or ecological states of the system.

Criterion 4: degree to which the social and ecological systems are treated in equal depth.

Binder et al. (2013) considered this to be an important criterion when choosing a framework. Of the 10 frameworks they investigated, only 1 was considered to meet this criterion; that of Ostrom $(2007,2009)$. The conceptual link between the latter, the approach of Anderies et al. (2004), and the SES-EA framework is referred to earlier. The SES-EA framework places social and 
Table 5. Evaluation of the degree to which the the social-ecological system environmental assessment (SES-EA) framework meets the requirements of environmental impact assessments (EIAs) in a South African legislative and policy context, using Binder et al. (2013).

\begin{tabular}{|c|c|c|}
\hline $\begin{array}{l}\text { Key attributes of frameworks for analyzing } \\
\text { social-ecological systems }\end{array}$ & $\begin{array}{l}\text { Requirements for environmental impact } \\
\text { assessments (EIAs) in a South African legislative } \\
\text { and policy context }\end{array}$ & $\begin{array}{l}\text { Degree to which the SES-EA framework meets } \\
\text { the requirements }\end{array}$ \\
\hline $\begin{array}{l}\text { Conceptualization of the social system in terms } \\
\text { of the inclusion of hierarchical levels and } \\
\text { dynamics }\end{array}$ & $\begin{array}{l}\text { - Micro to macro scale: } \\
\text { - social dynamics should be explicitly considered. }\end{array}$ & $\begin{array}{l}\text { - High: } \\
\text { - Micro to macro scale explicitly included. } \\
\text { - Several key elements of social dynamics } \\
\text { explicitly included. }\end{array}$ \\
\hline $\begin{array}{l}\text { Conceptualization of the ecological system in } \\
\text { terms of the inclusion of hierarchical levels and } \\
\text { dynamics }\end{array}$ & $\begin{array}{l}\text { - Micro to macro scale: } \\
\text { - Ecological dynamics should be explicitly } \\
\text { considered. }\end{array}$ & $\begin{array}{l}\text { - Moderately high: } \\
\text { - Micro to macro scale explicitly included, but the } \\
\text { internal dynamics of the ecological system are not } \\
\text { explicitly considered. }\end{array}$ \\
\hline $\begin{array}{l}\text { Conceptualization of the interaction between the } \\
\text { social and the ecological systems }\end{array}$ & - Should consider effects in both directions. & $\begin{array}{l}\text { - High: } \\
\text { - Effects in both directions are considered. }\end{array}$ \\
\hline $\begin{array}{l}\text { Degree to which the social and ecological systems } \\
\text { are treated } \\
\text { in equal depth }\end{array}$ & $\begin{array}{l}\text { - Should provide the option to treat the social and } \\
\text { ecological systems in equal depth. }\end{array}$ & $\begin{array}{l}\text { - High: } \\
\text { - Both systems are treated in almost equal depth. }\end{array}$ \\
\hline Ecocentric vs. anthropocentric & $\begin{array}{l}\text { - Should not be overly anthropocentric or overly } \\
\text { ecocentric. }\end{array}$ & $\begin{array}{l}\text { - Moderate: } \\
\text { - The ecological system is considered in terms of } \\
\text { its utility for humans, thus the framework is } \\
\text { biased toward anthropocentric impacts. }\end{array}$ \\
\hline $\begin{array}{l}\text { Orientation: analysis-oriented frameworks versus } \\
\text { action-oriented frameworks }\end{array}$ & - An action-oriented framework is required. & $\begin{array}{l}\text { - High: } \\
\text { - Identification of what action needs to be taken, } \\
\text { and by whom. }\end{array}$ \\
\hline
\end{tabular}

economic impacts at the same level of importance as the commonly considered biological, i.e., nonhuman, and natural physical environments, and views this as a coupled system. This also helps overcome the identified physical-biological bias of conventional matrix approaches.

Criterion 5: orientation: analysis-oriented frameworks versus action-oriented frameworks

Binder et al. (2013) distinguished between analysis-oriented frameworks, which are more suited to framing research questions, and action-oriented frameworks, which are aimed at interventions. The SES-EA framework is an action-based framework, which provides a methodological approach to obtaining and understanding what information is required to be taken, and from whom.

Application of the SES-EA framework in each of the case studies illustrates the value of attempting to formally describe and define the associated SES. Creating a conceptual model in this way helps build a more holistic understanding of the complex interrelationships between the four structural elements (Fig. 2). Once the conceptual model is defined completely, the interlinkages between components provide the basis for defining the interrelationships in the SES-matrix (Table 5). The SESmatrix is therefore specific to, and appropriate for, the project. This overcomes one of the major weaknesses of conventional matrix approaches of being either too detailed for some projects or not precise enough for others (FAO 1996, Glasson et al. 2012).

In summary, the SES-EA framework supports the identification and understanding of (1) a variety of different levels of the social system; (2) a variety of different levels of the ecological system; and (3) the interrelationships between these two systems. Importantly it gives equal emphasis to both the ecological and social systems.
Does it provide a means of effectively communicating impacts? Public participation is an essential component of any EIA process, and more so in South African EIA legislation (Government of South Africa 2010) in which public participation must be meaningful, with a further requirement to bridge impediments to participation. For example, Regulation $542 \mathrm{e}$ requires that the EAP gives notice of a proposed development "using reasonable alternative methods... where a person is desiring of but unable to participate in the process due to - (i) illiteracy; (ii) disability; or (iii) any other disadvantage."

The advantage of using the SES-EA framework is that the process of conceptualizing the SES helps identify the beneficiaries of ecosystem services. Stakeholders are therefore identified more directly, rather than by relying on conventional advertising, which limits participation to the literate. Similarly, through identifying the public infrastructure providers, additional stakeholders can be identified. Identifying stakeholders while developing an understanding of the coupled social-ecological system makes it far less likely that key stakeholders would be missed.

Recent reviews of EIA practice highlight the challenges around the critical role of public participation in EIA, calling for "cultural change" and recognition of the "importance of different forms of social and organizational learning through participatory approaches" (Morgan 2012:10). For example Pope et al. (2013:5) suggested trends "toward more deliberative and empowering forms of engagement have been slow" and also recognized the need to recast public participation as a process of social learning and transformation. One of the ways in which Stirzaker et al. (2010:605) suggested requisite simplicities can be identified is by developing "empathy for other knowledge forms such as culture and experience and spending time learning together." 
We suggest that the participatory methodology at the heart of the approach goes well beyond traditional EIA practice and makes an important contribution in addressing these challenges. Both case studies used participatory workshops to better understand the associated SES and the likely implications and impacts of development proposals, and a variety of stakeholders including community and local government representatives participated in this process. Stakeholders identified ecosystem services important to them and learned about the extent and nature of the ecosystems that sustain them. Other stakeholders could recognize the importance of resources to other participants and how their activities might have an impact on these resources. Application of the framework allowed the complexities and interrelationships to be exposed with all parties contributing and sharing; new understanding of the system was thus cocreated. Once an understanding of the system is in place, it is much easier for stakeholders to describe and understand impacts to the system. Furthermore because impacts are related directly to ecosystems services that are important to them, potential impacts can be perceived more readily.

\section{Does it promote an integrated, comprehensive, and detailed understanding of the impacts?}

South African EIA regulations require that an EIA must provide a description of the "manner in which the geographical, physical, biological, social, economic and cultural aspects of the environment may be affected by the proposed activity" (Government of South Africa 2010; subsection 2d of regulation 22 and 31 of GNR 543). Step 1 of phase 1 of the SES-EA framework requires identification of the geographical, biological, and natural physical environments a proposed development will have an impact on. Step 1 of phase 2 of the framework requires identification of the social, built physical, and cultural environments a proposed development will have an impact on. Implementing the framework in this sequential and systematic way therefore ensures that all aspects of the environment are addressed.

For example, the approach enabled identification of the potential secondary negative visual impact a sand-winning operation might have on location desirability from an ecotourism perspective. This is unlikely to have been identified in a conventional EIA process focused on the biophysical impacts associated with establishing the accommodation facility. Sand-winning was also considered to have a likely secondary impact on the quality of roads, because large trucks would need to utilize the local road network. In this case study, the framework facilitated a more comprehensive understanding of the direct and indirect impacts associated with the proposed development, which in turn enabled the identification of potential mitigation measures, essential for sustainability of the project and the resource.

One possible mitigation measure identified was for the sandwinning operation to be moved to an alternative site, away from the view of the accommodation. However, consideration of the SES in more detail revealed that the sand-winning operation was subsidizing road maintenance, normally the sole responsibility of the local authority. The implication of this being that future local government participation would be essential to the success of the development, because they would need to be responsible for maintaining the access road on which the development would be dependent.
Although relatively straightforward, what this case study illustrated was the benefit of having a mechanism to depict complex interdependencies in an SES, and therefore an effective means to explore the advantages and disadvantages of proposals with stakeholders. In this respect, the SES-EA framework proved a useful adjunct to conventional EIA tools.

Response of statutory agencies to the framework was encouraging. In the case of the estuary project, there was a crosssection of statutory bodies from which to canvas opinions. In the case of the residential wine estate, we reviewed the application of the framework with representatives of key government departments, including the Department of Water Affairs, KwaZulu-Natal Wildlife, local and district municipality representatives, as well as the environmental officer responsible for assessing the EIA and authorizing the project. This official indicated that use of the approach had clearly (1) enabled the potential impacts associated with the development to be systemically considered and logically understood; and (2) instilled a greater level of confidence in the information presented in the EIA, in comparison to a usual EIA, because with the new approach it was much clearer that the impacts of the development were considered holistically and thoroughly, and not in isolation. Although these views are anecdotal and qualitative, they nevertheless suggest that the approach has merit and that further testing and evaluation would be beneficial, particularly in relation to the call by Weaver et al. (2008:97) to push "the sustainability vectors on every EIA an individual works on."

\section{Limitations}

The core SES conceptualization of the framework takes an anthropocentric view, and although it considers ecosystems broadly, the emphasis is on ecosystem services directly relevant to human well-being, raising the possibility that some biophysical impacts might be overlooked. Similarly, because the focus is between the social and biophysical, interactions between components of ecosystems may not be considered. This resonates with the broader debate concerning the relationship between EIA and SIA and the merits of complete integration; some have concerns that biophysical concerns will be diluted (Smith and Sheate 2001, Hacking and Guthrie 2008) or that biophysical impacts will receive less attention because of further resource and time constraints imposed by considering socioeconomic impact concurrently (Scrase and Sheate 2002). Our response would be that the framework is not intended to replace what biophysical assessment would ordinarily be done in an EIA, it is an additional mechanism for exploring interdependencies between the social and biophysical.

Assessment of ecosystem services is a relatively new field, and EIA practitioners may not have adequate knowledge and skill in this area. Our approach relies on basic rather than expert knowledge in this field, but the implication is nevertheless that the broader team should include this expertise, and that EIA practitioners should seek out training in this important and developing area.

One area of EIA practice, which is acknowledged as being weak internationally, is that of cumulative impact assessment (Morgan 2012, Pope et al. 2013). In South Africa, there is the expectation that cumulative impacts will be assessed; subsections $2 \mathrm{i}$ of Regulation 22 and 21 of Regulation 31 require a description and assessment of the significance of any environmental impacts, 
including cumulative impacts, which may occur as a result of the undertaking of the activity. Matrix approaches are acknowledged to have limited value in identifying cumulative impacts, particularly at higher orders (Table 1). Although the SES-EA framework would probably provide a strong foundation for considering cumulative impacts, this would need to be a subsequent activity supported by other approaches.

The SES conceptualization is based on the initial work of Anderies et al. (2004) and Ostrom (2007, 2009). We are aware there has been an evolving discussion of this framework, which has recently been formalized further (McGinnis and Ostrom 2014). Although the fundamental principle is the same, our approach would doubtless benefit from extension via these most recent developments.

\section{CONCLUSIONS}

We have shown that the process of systematically defining the SES helps describe and explore potential interrelationships in a more useful way than conventional matrix approaches. The process helps identify stakeholders who are beneficiaries of ecosystem services, but also those responsible for providing infrastructure to maintain the supply of ecosystem services, thereby promoting more complete public participation. Coproduction of the SES also provides a platform for discussing, understanding, and communicating impacts between and among stakeholders, thereby fostering social learning and effective public participation in EIA.

We suggest that the framework addresses the three criteria proposed by Hacking and Guthrie (2008; Fig. 1). Comprehensiveness is achieved by promoting the consideration of all six aspects of the environment, with equal attention given to the social and ecological systems, and integratedness is addressed by providing a mechanism to identify and understand interlinkages between the components of an SES at a range of social scales. The framework addresses strategicness by encouraging an EAP to understand the environmental implications of a development at a broad, systemic scale initially, but then, in accordance with the approach of requisite simplicity (Stirzaker et al. 2010), allows the EAP to focus down on the specific issues that may have an impact on the supply of ecosystem services. An additional advantage is that the approach helps identify the ancillary infrastructure requirements and those who may be responsible for its supply and maintenance. This is frequently a cause of failure in development projects because the project has been decided in isolation.

We are also encouraged by the potential in the approach recognized by statutory agencies, but acknowledge that further application and evaluation is required. The framework is also not intended as a completely stand-alone approach or a replacement for matrix or network approaches; it is an adjunct to existing methods, which may have particular relevance in the case of complex SESs. More work is required to develop new tools or to link existing methods to abstract the data, information, and understanding required to implement each step, particularly in relation to the quantification of impacts.

In the interim, we propose that it could be used in South Africa and other developing countries by EAPs, and in the review of EIAs, and as a counterpoint to more traditional approaches. We hope that application in either sense would improve the quality of EIAs with respect to the complex SESs, which characterize much of the developing world. We suggest that by explicitly incorporating resilience and ecosystem services into impact assessment, the framework contributes to some of the emerging opportunities for EIA practice identified by Pope et al. (2013).

Responses to this article can be read online at: http://www.ecologyandsociety.org/issues/responses. $\mathrm{php} / 7057$

\section{Acknowledgments:}

Dr. Steve Mitchell of the South African Water Research Commission and Dr. Andrew Mather of eThekwini Municipality, KwaZulu-Natal, for their valuable input into the development of this framework. Funding for this project came from the South African Water Research Commission: Estuaries and Economic Empowerment project.

\section{LITERATURE CITED}

Akintunde, M. A., and A. Olajide. 2011. Environmental impact assessment of Nigerian National Petroleum Corporation (NNPC) Awka Mega Station. American Journal of Scientific and Industrial Research 2(4):511-520. http://dx.doi.org/10.5251/ ajsir.2011.2.4.511.520

Anderies, J. M., M. A. Janssen, and E. Ostrom. 2004. A framework to analyze the robustness of social-ecological systems from an institutional perspective. Ecology and Society 9(1): 18. [online] URL: http://www.ecologyandsociety.org/vol9/iss1/art18/

Baker, J., W. R. Sheate, P. Phillips, and R. Eales. 2013. Ecosystem services in environmental assessment - help or hindrance? Environmental Impact Assessment Review 40:3-13. http://dx.doi. org/10.1016/j.eiar.2012.11.004

Barbour, T. 2007. Guideline for involving social assessment specialists in EIA processes. Department of Environmental Affairs and Development Planning, Western Cape Province, Cape Town, South Africa. [online] URL: http://www.asapa.org.za/ uploads/files/guideline involving_social_assessment_specialists_eia process.pdf

Barrow, C. J. 1997. Environmental and social impact assessment: an introduction. Arnold, London, UK.

Binder, C. R., J. Hinkel, P. W. G. Bots, and C. Pahl-Wostl. 2013. Comparison of frameworks for analyzing social-ecological systems. Ecology and Society 18(4): 26. http://dx.doi.org/10.5751/ ES-05551-180426

Bojórquez-Tapia, L. A., E. Ezcurra, and O. García. 1998. Appraisal of environmental impacts and mitigation measures through mathematical matrices. Journal of Environmental Management 53:91-98. http://dx.doi.org/10.1006/jema.1998.0191

Bond, A. J., and A. Morrison-Saunders. 2011. Re-evaluating sustainability assessment: aligning the vision and the practice. Environmental Impact Assessment Review 31:1-7. http://dx.doi. org/10.1016/j.eiar.2010.01.007 
Bond, A., A. Morrison-Saunders, and J. Pope. 2012. Sustainability assessment: the state of the art. Impact Assessment and Project Appraisal 30(1):53-62. http://dx.doi.org/10.1080/14615517.2012 .661974

Bowd, R., N. W. Quinn, D. C. Kotze, D. G. Hay, and M. Mander. 2012. The identification of potential resilient estuary-based enterprises to encourage economic empowerment in South Africa: a toolkit approach. Ecology and Society 17(3): 15. http:// dx.doi.org/10.5751/ES-04840-170315

Burdge, R. J. 2002. Why is social impact assessment the orphan of the assessment process? Impact Assessment and Project Appraisal 20(1):3-9. http://dx.doi.org/10.3152/147154602781766799

Burdge, R. J. 2003. Benefiting from the practice of social impact assessment. Impact Assessment and Project Appraisal 21:225-229. http://dx.doi.org/10.3152/147154603781766284

Canter, L. W. 1996. Environmental impact assessment. Second edition. McGraw-Hill, New York, New York, USA.

Canter, L. W. 2008. Conceptual models, matrices, networks, and adaptive management - emerging methods for CEA. Assessing and managing cumulative environmental effects conference, 6-9 November 2008. International Association for Impact Assessment, Calgary, Alberta, Canada. [online] URL: https:// www.iaia.org/IAIA08Calgary/documents/Conceptual $\% 20$ Models $\%$ 20Paper $\% 2012-08$.pdf

Cashmore, M. 2004. The role of science in environmental impact assessment: process and procedure versus purpose in the development of theory. Environmental Impact Assessment Review 24:403-426. http://dx.doi.org/10.1016/j.eiar.2003.12.002

Chadwick, A. 2002. socioeconomic impacts: are they still the poor relations in UK environmental statements? Journal of Environmental Planning and Management 45(1):3-24. http://dx. doi.org/10.1080/09640560120100169

Costanza, R., B. S. Low, E. Ostrom, and J. Wilson. 2001. Institutions, ecosystems and sustainability. Lewis, New York, New York, USA.

du Pisani, J. A., and L. A. Sandham. 2006. Assessing the performance of SIA in the EIA context: a case study of South Africa. Environmental Impact Assessment Review 26:707-724. http://dx.doi.org/10.1016/j.eiar.2006.07.002

Esteves, A. M., D. Franks, and F. Vanclay. 2012. Social impact assessment: the state of the art. Impact Assessment and Project Appraisal 30(1):34-42. http://dx.doi.org/10.1080/14615517.2012.660356

Fisher, L. 2011. The treatment of socio economic impacts in environmental impact statements. Thesis. University of East Anglia, Norwich, UK. [online] URL: http://www.uea.ac.uk/env/ all/teaching/eiaams/pdf dissertations/2011/Fisher_Laura 2011.pdf

Food and Agriculture Organization (FAO).1996. Environmental impact assessment and environmental auditing in the pulp and paper industry. Food and Agriculture Organization, Rome, Italy. [online] URL: http://www.fao.org/DOCREP/005/V9933E/V9933E00. HTM

Fuller, K. 1999. Quality and quality control in environmental impact assessment. Pages 55-78 in J. Petts, editor. Handbook of
Environmental Impact Assessment Volume 2. Wiley-Blackwell, Hoboken, New Jersey, USA.

Gibson, R. B. 2006. Sustainability assessment: the basic components of a practical approach. Impact Assessment and Project Appraisal 24(3):170-182. http://dx.doi.org/10.3152/1471$\underline{54606781765147}$

Glasson, J., and D. Heaney. 1993. socioeconomic impacts: the poor relations in British environmental impact statements. Journal of Environmental Planning and Management 36 (3):335-343. http://dx.doi.org/10.1080/09640569308711950

Glasson, J., R. Therivel, and A. Chadwick. 2012. Introduction to environmental impact assessment. Fourth edition. Taylor and Francis, New York, New York, USA.

Government of South Africa. 1998. Government gazette 19519: national environmental management act (NEMA). Act No. 107. Government of South Africa, Pretoria, South Africa.

Government of South Africa. 2010. Government gazette 33306: government notice regulation 543: national environmental management act (107/1998): environmental impact assessment regulations, South Africa. Government of South Africa, Pretoria, South Africa. [online] URL: https://www.environment.gov.za/ sites/default/files/legislations/nema impactassessment g33306rg9314gon543.pdf

Hacking, T., and P. Guthrie. 2008. Framework for clarifying the meaning of triple bottom-line, integrated, and sustainability assessment. Environmental Impact Assessment Review 28 (2-3):73-89. http://dx.doi.org/10.1016/j.eiar.2007.03.002

Hildebrand, L., and L. A. Sandham. 2014. Social impact assessment: the lesser sibling in the South African EIA process? Environmental Impact Assessment Review 48:20-26. http://dx.doi. org/10.1016/j.eiar.2014.04.003

International Association for Impact Assessment (IAIA). 1999. Principles of environmental impact assessment best practice. International Association for Impact Assessment, Fargo, North Dakota, USA. [online] URL: http://www.iaia.org/publicdocuments/ special-publications/Principles $\% 20$ of $\% 20 I A$ web.pdf

Kassim, T. A., and K. J. Williamson. 2005. Environmental impact assessment of recycled wastes on surface and ground waters. Volume 3: Engineering modeling and sustainability. The handbook of environmental chemistry, water pollution series. Vol. 5/Part F. Springer-Verlag, Berlin, Germany.

Kidd, M., and F. Retief. 2009. Environmental assessment. Pages 971-1047 in H. A. Strydom, N. D. King, R. Fuggle, and M. A. Rabie, editors. Environmental management in South Africa. Second edition. Juta, South Africa.

Lawrence, D. P. 2000. Planning theories and environmental impact assessment. Environmental Impact Assessment Review 20:607-625. http://dx.doi.org/10.1016/S0195-9255(00)00036-6

Leopold, L. B., F. E. Clarke, B. B. Hanshaw, and J. R. Balsley. 1971. A procedure for evaluating environmental impact. Geological Survey Circular 645. U.S. Geological Survey, Washington, D.C., USA. [online] URL: http://eps. berkeley.edu/people/lunaleopold/(118)\% $20 \mathrm{~A} \% 20$ Procedure $\% 20$ for $\% 20$ Evaluating $\% 20$ Environmental $\% 20$ Impact. pdf 
McGinnis, M. D., and E. Ostrom. 2014. Social-ecological system framework: initial changes and continuing challenges. Ecology and Society 19(2): 30. http://dx.doi.org/10.5751/ES-06387-190230

Modak, P., and A. K. Biswas. 1999. Conducting environmental impact assessment for developing countries. United Nations University Press, Tokyo, Japan.

Morgan, R. K. 2012. Environmental impact assessment: the state of the art. Impact Assessment and Project Appraisal 30(1):5-14. http://dx.doi.org/10.1080/14615517.2012.661557

Morris, P., and R. Therivel. 2009. Methods of environmental impact assessment. Third edition. Routldge, Abingdon, UK.

Morrison-Saunders, A., and F. Retief. 2012. Walking the sustainability assessment talk - progressing the practice of environmental impact assessment (EIA). Environmental Impact Assessment Review 36:34-41. http://dx.doi.org/10.1016/j.eiar.2012.04.001

Munn, R. E. 1979. Environmental impact assessment: principles and procedures. SCOPE Report 5. Second edition. John Wiley, Chichester, UK.

Noble, B. F. 2009. Introduction to environmental impact assessment: a guide to principles and practice. Second edition. Oxford University Press, New York, New York, USA.

Ogola, P. F. A. 2007. Environmental impact assessment general procedures. Presented at Short Course II on Surface Exploration for Geothermal Resources. Kenya Electricity Generating Company, Naivasha, Kenya. [online] URL: http://www.os.is/ gogn/unu-gtp-sc/UNU-GTP-SC-05-28.pdf

Ortolano, L., and A. Shepherd. 1995. Environmental impact assessment: challenges and opportunities. Impact Assessment 13 (1):3-30. http://dx.doi.org/10.1080/07349165.1995.9726076

Ostrom, E. 2007. A diagnostic approach for going beyond panaceas. Proceedings of the National Academy of Sciences 104 (39):15181-15187. http://dx.doi.org/10.1073/pnas.0702288104

Ostrom, E. 2009. A general framework for analyzing sustainability of social-ecological systems. Science 325:419-422. http://dx.doi.org/10.1126/science.1172133

Ostrom, E., and T. K. Ahn. 2003. Foundations of social capital. Edward Elgar, Cheltenham, UK.

Partidario, M. R., and R. C. Gomes. 2013. Ecosystem services inclusive strategic environmental assessment. Environmental Impact Assessment Review 40:36-46. http://dx.doi.org/10.1016/j. eiar.2013.01.001

Pastakia, C. M. R., and A. Jensen. 1998. The rapid impact assessment matrix (RIAM) for EIA. Environmental Impact Assessment Review 18:461-482. http://dx.doi.org/10.1016/ $\underline{\mathrm{S} 0195-9255(98) 00018-3}$

Peterson, G. L., R. S. Gemmel, and J. L. Shofer. 1974. Assessment of environmental impacts: multiple disciplinary judgments of large-scale projects. Ekistics 218:23-30.

Pope, J., A. Bond, A. Morrison-Saunders, and F. Retief. 2013. Advancing the theory and practice of impact assessment: setting the research agenda. Environmental Impact Assessment Review 41:1-9. http://dx.doi.org/10.1016/j.eiar.2013.01.008
Riddell, R. C. 2008. Does foreign aid really work? Oxford University Press, Oxford, UK.

Sandham, L. A., and H. M. Pretorius. 2008. A review of EIA report quality in the North West province of South Africa. Environmental Impact Assessment Review 28:229-240. http://dx. doi.org/10.1016/j.eiar.2007.07.002

Scrase, J. I., and W. R. Sheate. 2002. Integration and integrated approaches to assessment: what do they mean for the environment? Journal of Environmental Policy and Planning 4 (4):275-294. http://dx.doi.org/10.1002/jepp.117

Smit, B., and H. Spaling. 1995. Methods for cumulative effects assessment. Environmental Impact Assessment Review 15:81-106. http://dx.doi.org/10.1016/0195-9255(94)00027-X

Smith, S. P., and W. R. Sheate. 2001. Sustainability appraisals of regional planning guidance and regional economic strategies in England: an assessment. Journal of Environmental Planning and Management 44(5):735-755. http://dx.doi.org/10.1080/09640560120080009

Stirzaker, R., H. Biggs, D. Roux, and P. Cilliers. 2010. Requisite simplicities to help negotiate complex problems. AMBIO 39 (8):600-607. http://www.bioone.org/doi/full/10.1007/ s13280-010-0075-7 http://dx.doi.org/10.1007/s13280-010-0075-7

Sorensen, J. C. 1971. A framework for identification and control of resource degradation and conflict in the multiple use of the coastal zone. University of California Press, Berkeley, California, USA.

Taylor, C. N., C. H. Bryan, and C. G. Goodrich. 2004. Social assessment: theory process and techniques. Third edition. Social Ecology, Middleton, Wisconsin, USA.

Turnbull, R. G. H. 1992. Environmental and health impact assessment of development projects: a handbook for practitioners. Taylor and Francis, London, UK.

Vanclay F. 2003. International principles for social impact assessment. Impact Assessment and Project Appraisal 21(1):5-12. http://dx.doi.org/10.3152/147154603781766491

Walker, B., S. Carpenter, J. Anderies, N. Abel, G. S. Cumming, M. Janssen, L. Lebel, J. Norberg, G. D. Peterson, and R. Pritchard. 2002. Resilience management in social-ecological systems: a working hypothesis for a participatory approach. Conservation Ecology 6(1): 14. [online] URL: http://www. consecol.org/vol6/iss1/art14/

Weaver, A., J. Pope, A. Morrison-Saunders, and P. Lochner. 2008. Contributing to sustainability as an environmental impact assessment practitioner. Impact Assessment and Project Appraisal 26:91-98. http://dx.doi.org/10.3152/146155108X316423

Wood, C. 1999. Screening and scoping. Pages 71-84 in N. Lee and C. George, editors. Environmental assessment in developing and transitional countries. John Wiley and Sons, Chichester, UK.

Wood, C. 2003. Environmental impact assessment: a comparative review. Second edition. Prentice Hall, Harlow, UK. 